\title{
Speleothem evidence for MIS $5 c$ and 5a sea level above modern level at Bermuda
}

\author{
Karine A.I. Wainer ${ }^{\mathrm{a}, *}$, Mark P. Rowe ${ }^{\mathrm{b}}$, Alexander L. Thomas ${ }^{\mathrm{c}}$, Andrew J. Mason ${ }^{\mathrm{a}}$, \\ Bruce Williams ${ }^{\mathrm{d}}$, Mark E. Tamisiea ${ }^{\mathrm{e}}$, Felicity H. Williams ${ }^{\mathrm{f}}$, André Düsterhus ${ }^{\mathrm{g}}$, Gideon \\ M. Henderson ${ }^{a}$ \\ a Department of Earth Sciences, Oxford University, South Parks Road, Oxford OX1 3AN, UK \\ ${ }^{b}$ Department of Earth and Planetary Sciences, Birkbeck University of London, Malet Street, Bloomsbury, London WC1E 7HX, UK \\ c University of Edinburgh, West Mains Road, Edinburgh EH93JW, UK \\ d Bermuda Institute of Ocean Sciences, Bermuda \\ e National Oceanography Centre, Joseph Proudman Building, 6 Brownlow Street, Liverpool L3 5DA, UK \\ ${ }^{\mathrm{f}}$ National Oceanography Centre, University of Southampton, Waterfront Campus, European Way, Southampton SO14 3ZH, UK \\ g Institute of Oceanography, Centre for Earth System Research and Sustainability (CEN), University of Hamburg, Bundesstrasse 53, 20146 Hamburg, Germany
}

\section{A R T I C L E I N F O}

\section{Article history:}

Received 13 January 2016

Received in revised form 5 October 2016

Accepted 7 October 2016

Available online 2 November 2016

Editor: H. Stoll

\section{Keywords:}

speleothem

sea level

Bermuda

isostasy

U-Th ages

forebulge

\begin{abstract}
A B S T R A C T
The history of sea level in regions impacted by glacio-isostasy provides constraints on past ice-sheet distribution and on the characteristics of deformation of the planet in response to loading. The Western North Atlantic-Caribbean region, and Bermuda in particular, is strongly affected by the glacial forebulge that forms as a result of the Laurentide ice-sheet present during glacial periods. The timing of growth of speleothems, at elevations close to sea level can provide records of minimum relative sea level (RSL). In this study we used U-Th dating to precisely date growth periods of speleothems from Bermuda which were found close to modern-day sea level. Results suggest that RSL at this location was above modern during MIS5e, MIS5c and MIS5a. These data support controversial previous indications that Bermudian RSL was significantly higher than RSL at other locations during MIS $5 c$ and MIS $5 \mathrm{a}$. We confirm that it is possible to explain a wide range of MIS5c-a relative sea levels observed across the Western North Atlantic-Caribbean in glacial isostatic adjustment models, but only with a limited range of mantle deformation constants. This study demonstrates the particular power of Bermuda as a gauge for response of the forebulge to glacial loading, and demonstrates the potential for highstands at this location to be significantly higher than in other regions, helping to explain the high sea levels observed for Bermuda from earlier highstands.
\end{abstract}

(c) 2016 Elsevier B.V. All rights reserved.

\section{Introduction}

Bermuda is situated on the forebulge resulting from ice loading on North America during glacial periods (Fig. 1). Relative sea level (RSL) at Bermuda therefore has potential to provide information about the deformation parameters of the Earth, and/or about the distribution of past Laurentide and Greenland ice sheets. Conditions appear favourable for reconstruction of such RSL: tectonic

\footnotetext{
* Corresponding author.

E-mail addresses: karinewainer@gmail.com (K.A.I. Wainer), markprowe@gmail.com (M.P. Rowe), alex.thomas@ed.ac.uk (A.L. Thomas), andrewm@earth.ox.ac.uk (A.J. Mason), Bruce.Williams@bios.edu (B. Williams), metamisiea@gmail.com (M.E. Tamisiea), Felicity.Williams@noc.soton.ac.uk (F.H. Williams), andre.duesterhus@uni-hamburg.de (A. Düsterhus), gideonh@earth.ox.ac.uk (G.M. Henderson).
}

activity is limited, and conditions are appropriate for both coral development and speleothem growth, allowing the use of two of the most robust sea-level archives that can be directly dated during this time interval. Nevertheless, the sea-level history of Bermuda remains uncertain (e.g. Hearty, 2002; Rowe et al., 2014), with the amplitude of highstands during the last interglacial complex (e.g. Marine Isotope Stage 5; MIS 5) being particularly controversial.

It is now widely accepted that peak eustatic (i.e. global ocean mass equivalent) sea level of the Last Interglacial (e.g. MIS 5e), was above modern (e.g. Dutton and Lambeck, 2012; Dutton et al., 2015; Kopp et al., 2009). The amplitude of subsequent smaller highstands during MIS 5c ( 106-93 ka) and 5a (85-74 ka) is, however, generally more controversial. For MIS $5 \mathrm{a}$, which is the better documented of the two, a large range of RSL has been reported around the globe, ranging from $-30 \mathrm{~m}$ at the Huon Peninsula, Papua New Guinea (Lambeck and Chappell, 2001) to $+5 \mathrm{~m}$ on the Atlantic 


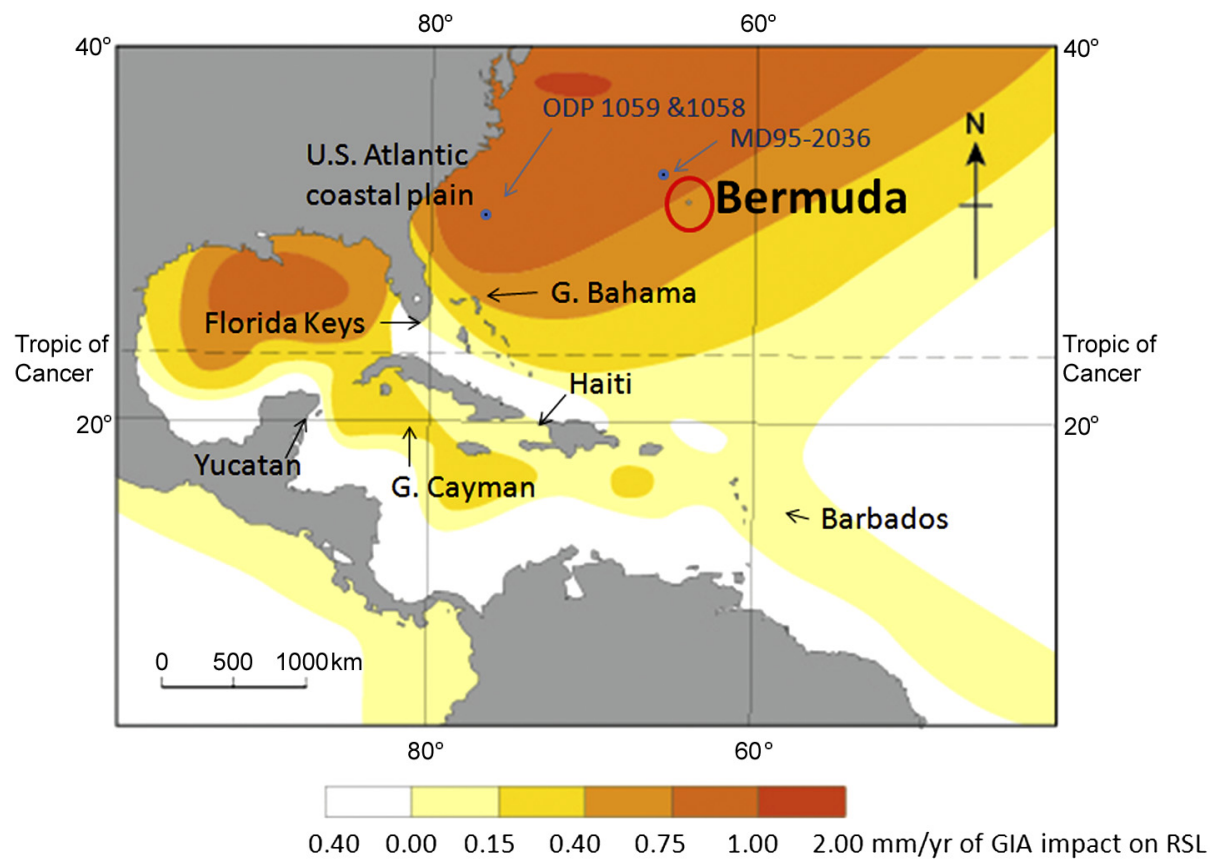

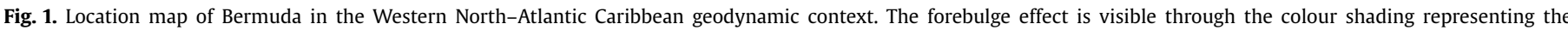

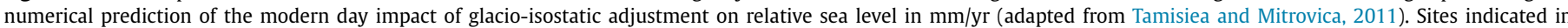

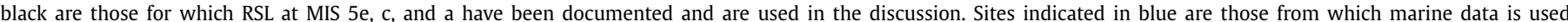
for comparison. (For interpretation of the references to colour in this figure legend, the reader is referred to the web version of this article.)

coast of the US (Wehmiller et al., 2004). Within the Western North Atlantic-Caribbean (WNAC) region, the MIS 5a highstand has been reported at elevations ranging from -22 to $+5 \mathrm{~m}$ (e.g. Dodge et al., 1983; Dumas et al., 2006; Ludwig et al., 1996; Lundberg and Ford, 1994; Moseley et al., 2013; Muhs et al., 2002; Radtke and Schellmann, 2005; Richards et al., 1994; Toscano and Lundberg, 1999; Vacher and Hearty, 1989; Wehmiller et al., 2004). Such variability in WNAC RSL has been explained by glacio-isostatic adjustment (GIA) associated with the glacial forebulge (Potter and Lambeck, 2003). RSL in the North of the WNAC region is characterised particularly well by Bermuda, because it is a place where RSL records are available and is close to where GIA has the greater impact associated to the bulge (Fig. 1). This makes accurate knowledge of RSL at Bermuda particularly useful, not principally for the information it provides about eustatic sea level, but for the constraints it provides on Earth deformation and regional ice sheet histories.

In this study, we present new MIS5 RSL data for Bermuda, based on high-resolution U-Th dating of speleothems. Speleothems are generally protected from weathering and many forms of erosion by their location, and can provide powerful archives of past sea-level change. Speleothems are also generally sampled when in growth position, and can only accrete when above sea level, thus periods of growth robustly indicate RSL below their site of formation (Harmon et al., 1978; Moseley et al., 2013; Van Hengstum et al., 2015). Hiatuses in speleothem growth indicate possible periods when sea level was above that level, but are less robust indicators because other factors may lead to pauses in growth.

\section{Background}

\subsection{MIS5 past sea-level reconstruction at Bermuda}

The MIS5e highstand at Bermuda was higher than modern, as demonstrated by coral occurrences up to $+6 \mathrm{~m}$, and a marine aragonite overgrowth on a stalactite from Crystal Cave which developed during that period at +3 to $+4 \mathrm{~m}$ (Harmon et al., 1981, 1983, 1978). There are also a number of well-documented marine conglomerates up to at least $+9 \mathrm{~m}$ above modern sea level which, on the basis of U-series age data from numerous coral fragments within them, can be attributed to MIS5e (Harmon et al., 1983; Hearty and Kindler, 1995; Land et al., 1967; Meischner et al., 1995; Muhs et al., 2002). So although the elevation of MIS5e RSL at Bermuda is not precisely established, it was clearly above presentday level (Fig. 2).

On the contrary, the height of MIS $5 c$ and $5 \mathrm{a}$ highstands at Bermuda is a contentious subject. Evidence for the height of the MIS5c RSL highstand includes (Fig. 2):

- RSL above $-6 \mathrm{~m}$ based on synchronous termination of growth of two speleothems; coral fragments up to several meters above sea level dated $\sim 100 \mathrm{ka}$ (Harmon et al., 1978);

- RSL below $-15 \mathrm{~m}$ based on a speleothem growing continuously from $110 \mathrm{ka}$ to the Holocene at $-15 \mathrm{~m}$, and on amino acid racemization ages on eolianites at $\sim 105$ (Harmon et al., 1981);

- RSL above $-15 \mathrm{~m}$ provided by rare corals in growth position dated from 105 to 97 ka (Vollbrecht, 1990);

Similar controversy exists for RSL during the MIS5a highstand (Fig. 2):

- RSL at 1-2 m based on a cluster of ages on coral fragments from 82 to $78 \mathrm{ka}$ (Ludwig et al., 1996)

- RSL at a couple of meters above modern based on a cluster of ages on coral fragments from 84 to 78 ka (Muhs et al., 2002)

- RSL at 0-1 m based on amino-acid racemization data on land snails in a sub-aerial eolinite (Vacher and Hearty, 1989)

The strongest evidence suggesting RSL below modern for both MIS5c and 5a highstands is the continuous speleothem growth documented at $-15 \mathrm{~m}$ from $110 \mathrm{ka}$ to the Holocene (Harmon et al., 1981). The associated chronology for this sample is not completely robust due to the low precision and small number of $\alpha$-counting U-Th ages. Potter and Lambeck (2003) suggested that 


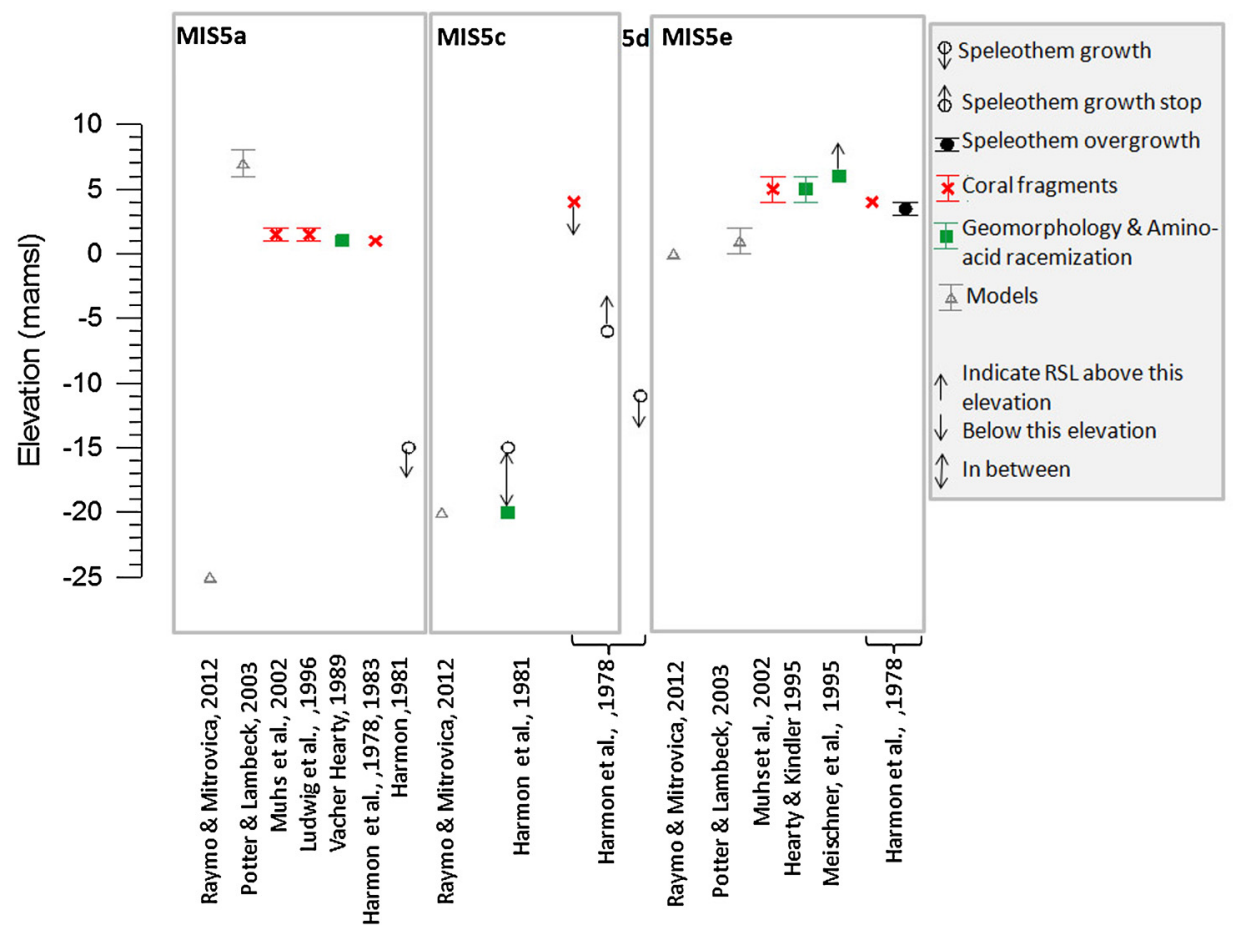

Fig. 2. Summary of the relevant RSL data available for the MIS5 at Bermuda. Note the disagreement existing for the RSL at MIS5c and 5a.

the lack of a correction for initial Th might also explain the discrepancy between this RSL indicator and the rest of the literature, but the low ${ }^{232} \mathrm{Th}$ content of this sample argues against incorporation of significant initial ${ }^{230} \mathrm{Th}$. It is perhaps more likely that the large quantity of material needed for dating by $\alpha$-counting impedes establishment of a fine chronology to reveal potential hiatuses.

The strongest evidence for RSL above modern sea-level during MIS5c and 5a comes from the multiple coral fragment ages. The fact that these corals are not in life position, however, makes this constraint less robust. Ludwig et al. (1996) and Muhs et al. (2002) ruled out re-working on the basis of the exclusivity of the ages within the deposit, an idea supported recently by Rowe et al. (2014). Other authors have suggested that the coral fragments are found in storm deposits above sea level (e.g. Harmon et al., 1983), although this was considered improbable given their position behind a wide reef-rimmed shallow lagoon (Vacher and Hearty, 1989).

The height of RSL at Bermuda during MIS5c and 5a therefore remains a controversial subject, reflected as well in various GIA models of the region which place it from above modern (Potter and Lambeck, 2003) to -20 m (Raymo and Mitrovica, 2012). Lack of robust observational constraint on the height of Bermuda RSL prevents the reliable use of this location to refine such GIA models and fulfil the potential of Bermuda as a recorder of the behaviour of the forebulge during ice-sheet loading and unloading. New evidence for RSL height during these periods are required to achieve that potential.

\subsection{Multiple highstands during MIS5a in the Northern Hemisphere}

In the WNAC, some records like terrace-coral records from Haiti and Barbados proposed multiple highstands during MIS5e, $5 \mathrm{c}$ and 5a (e.g. Radtke and Schellmann, 2005; Dumas et al., 2006). Regarding MIS5a, a consensus seems to identify a double highstand with an early short lived highstand centred on $84 \mathrm{ka}$ and a second one centred on 77 ka (Dumas et al., 2006; Potter et al., 2004;
Potter and Lambeck, 2003). A similar double peak feature is observed in the percentage of Quercus pollen in the nearby marine core, ODP1059, attesting that climate in the SE United States experienced two distinct warmer episodes coeval to these highstand peaks (Heusser and Oppo, 2003). Outside the WNAC area during MIS5a, the Red Sea record yields multiple sea-level oscillations of decreasing height (Rohling et al., 2009) and a submerged speleothems study in the Adriatic Sea, documents two highstand peaks, from 87 to $82 \mathrm{ka}$ and from 77 to 64 ka (Surić et al., 2009). Although some of these locations are tectonically unstable, this suggests that high frequency fluctuations of sea level during MIS5a may have been a global feature. Evidence from more tectonically stable locations, such as Bermuda, would help to confirm or refute this suggestion.

\section{Site}

Bermuda $\left(32.3^{\circ} \mathrm{N}, 64.8^{\circ} \mathrm{W}\right)$ is a volcanic seamount with a continuous carbonate cap located in the central-western Atlantic (Fig. 1). It consists of a group of islands which were formed principally as a result of short-distance wind transportation, accumulation and lithification of carbonate grains and debris produced on the marine platform during sea-level cycles. Numerous caves have developed in the oldest formations of these carbonate islands. Climate in Bermuda, largely influenced by its location in the path of the Westerlies, is subtropical and humid with mean annual air temperature $\sim 21^{\circ} \mathrm{C}$ and average rainfall $\sim 1500 \mathrm{~mm} / \mathrm{yr}$.

For this study, we sampled five caves. Key samples come from Wilkinson Quarry Cave, located on the north shore of the main island of Bermuda $\left(32^{\circ} 21^{\prime} \mathrm{N}, 64^{\circ} 42^{\prime} \mathrm{W}\right.$, Fig. S4). Access to the cave is no longer possible due to the danger of collapse caused by extensive work in the overlying quarry. This danger prevents contemporary monitoring of environmental parameters in this particular cave, but neighbouring Squeeze Cave, Admiral's Cave, Crystal Cave and Walsingham Cave, are within $1 \mathrm{~km}$ and provide information about the characteristics of karstic sites in the area. The location of all caves is shown on Fig. S4 in the supplemental material. 


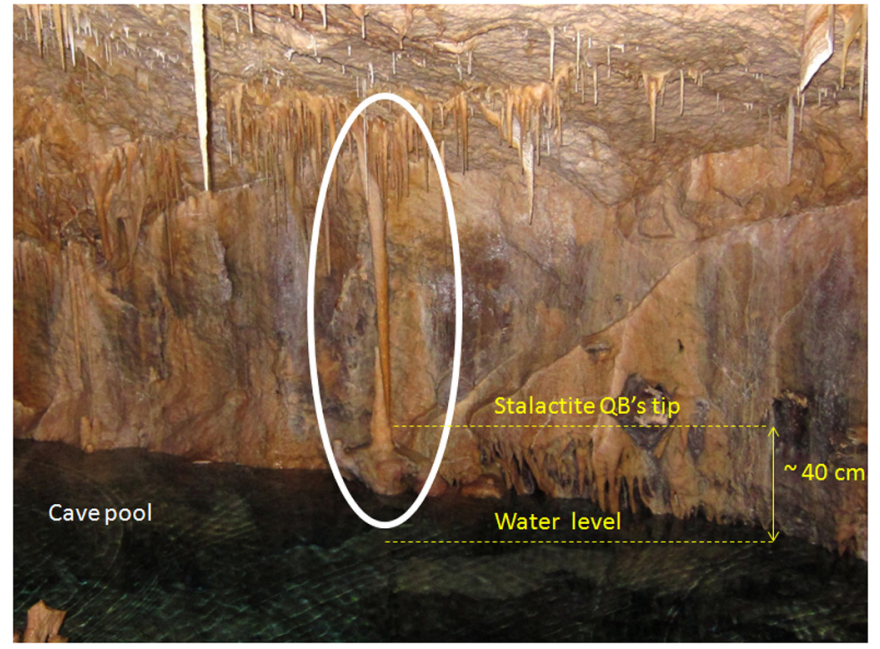

Fig. 3. Picture of the QB stalactite in Wilkinson Quarry Cave. The ceiling is at $1.5 \pm$ $0.5 \mathrm{~m}$ above the mean tidal height of the surface of the cave pool.

\section{Water level monitoring}

Wilkinson Quarry, Squeeze, Admiral's, Crystal and Walsingham caves are well connected to the ocean largely through secondary dissolved passageways and have water levels that are close to sea level but with the tidal cycle somewhat damped and lagged. Typically, the tidal average range over a complete year is $0.5 \mathrm{~m}$ inside these caves compared to $0.8 \mathrm{~m}$ in the open ocean (NOAA data), and lagged by $\approx 1-2 \mathrm{~h}$ (Fig. S5).

Rainwater percolation to the karst water table creates brackish water lenses, resulting in lower water density and therefore slightly higher water levels in caves than the ocean (e.g. van Hengstum et al., 2009). Such deviations are expected to be very small, however. Water-table gradients observed in the similar setting of the Yucatan, Mexico, are only $5-10 \mathrm{~mm} \mathrm{~km}^{-1}$ (Marin and Perry, 1994), and the Bermuda caves of this study are less than $0.3 \mathrm{~km}$ from the coast. Water levels in the caves can thus be considered as oscillating around the same elevation as sea level (Boop et al., 2014).

\section{Materials and methods}

This study focuses on sample QB (Fig. 3), a stalactite $1.10 \mathrm{~m}$ long derived from a narrow cave curtain hanging from a ceiling $\sim 1.5 \mathrm{~m}$ above sea level (masl, where sea level refers to the present mean tide level) in Wilkinson Quarry Cave (Figs. 3 and S2). Most of the work presented here was performed on two slices cut perpendicular to the growth axis at 1.37 (slice B1Bi) and 1.28 (slice B1Cii) masl (Figs. 4, 5 and S1). The width of the sample is $6.5 \mathrm{~cm}$ at the B1Cii slice (Fig. 4). XRD analyses demonstrate that the sample is calcite. It has a columnar crystalline fabric, with the original stalactite composed of dense dark calcite (DCC). The immediately subsequent growth-unit is composed of white porous calcite (WPC) with large easily breakable crystals, with the remaining growthunits ranging from dark dense to milky calcite.

Visual inspection of slices through the stalactite reveals five discontinuities (labelled D1 to D5; Fig. 4, Tables 1 and S1), corresponding to possible hiatuses. Microscope inspection of these discontinuities confirms the presence of perturbations in growth. The first of these, D1, marks the boundary of the central sodastraw portion of growth from the rest of the stalactite on B1Cii, with an abrupt change from DCC to WPC. Discontinuities D3 and D4 are characterised by an abrupt change from DCC to a few millimetres of more porous calcite. The same applies to D5 except that porous calcite is observed towards the exterior of the sample. New generations of crystals with competitive growth are identified all along D2 and in some places along D4. Thin clay layer deposits are visible at D3, 4 and 5 (Fig. 4).

Sixteen U-Th ages were performed to assess the chronology of the $\mathrm{QB}$ stalactite, and to assess possible periods of hiatus. The locations of the subsamples used are reported relative to a horizontal axis on the B1Cii slice, using petrographic features as a guide to compare data from other slices (Figs. 5 and S1). Details of the UTh methods broadly follow (Mason and Henderson, 2010) and are given in the supplementary material. Ages are reported relative to 1950. An age-depth model was constructed using the OxCal-4-2 software (Ramsey, 2008), which adds the constraint that all UTh ages have to be in stratigraphic order (Fig. 5). The age model is used to extrapolate the U-Th ages of samples from between growth boundaries to ascertain the hiatus ages. The deposition rate is controlled using P_Sequences, assuming random Poisson processes and allowing growth-rate fluctuations (see supp. mat. for detailed parameters).

Samples from Walsingham Cave, Squeeze Cave, Admiral's Cave, Crystal Cave and others from Wilkinson Quarry Cave, as well as pieces of flowstone retrieved from the shore cliff at Camp St David, were also dated as part of this study. These samples ranged in height relative to sea level from -14 to $+12 \mathrm{~m}$. They do not provide information used here to constrain sea level, but the age of their growth is used in discussion of the sea-level results. Full details and results for these other samples are provided in the Supplemental Material.

\section{Results}

All but one of the U-Th ages for the QB stalactite are in stratigraphic order within their dating uncertainties (Table S1; Fig. 5). The sample grew from late MIS6 $(141.5 \pm 2.2 \mathrm{ka})$ to late MIS5a $(72.9 \pm 1.4 \mathrm{ka})$. Notable steps in age are observed in the sample at depths corresponding to D1 and D2, and possible steps also seen at D3 and D4 (Fig. 5). The OxCal age-depth model provides a probabilistic assessment of the timing and duration of growth hiatuses associated with these steps in age, with hiatuses starting at $137 \pm 5,106 \pm 6,84.3 \pm 1.5$, and $79.9 \pm 0.9 \mathrm{ka}$ (Table 1 ), broadly correlating with the sea-level highstands of MIS5 recorded at other sites worldwide (e.g. Fig. 6), as recorded by the continuous Red Sea record (Grant et al., 2012; Siddall et al., 2003).

A total of 61 dates were obtained on the 17 other samples from Wilkinson Quarry Cave, Squeeze Cave, Crystal Cave, Walsingham Cave, Admiral's Cave and on flowstones of Camp St David dated within this study (Table S2, Fig. S3). The growth episodes documented are equally distributed during glacial, interglacial and intermediate climate episodes from MIS7 (Admiral's stalagmite, $216.0 \pm 4 \mathrm{ka}$ ) to recent Holocene (Squeeze S3, $4.5 \pm 1.1 \mathrm{ka}$ ). Holocene and Termination I are the most represented probably due to easier access to this younger period. Samples collected at greater depth $(-14 \mathrm{~m})$ grew during the last glacial. Growth episodes during part of MIS7, MIS6, late MIS5b and MIS5a were documented in the highest sample, from +10 masl, the Admiral's Cave giant stalagmite.

\section{Discussion}

\subsection{Are the four growth hiatuses due to sea-level rise?}

The correlation of growth hiatuses (D1 to D4) with known periods of sea-level highstand suggest that flooding of stalagmite QB may be responsible for these hiatuses. Other possible explanations are a change in the local flow conditions in the cave, or a change in climate towards more arid conditions at these times. 


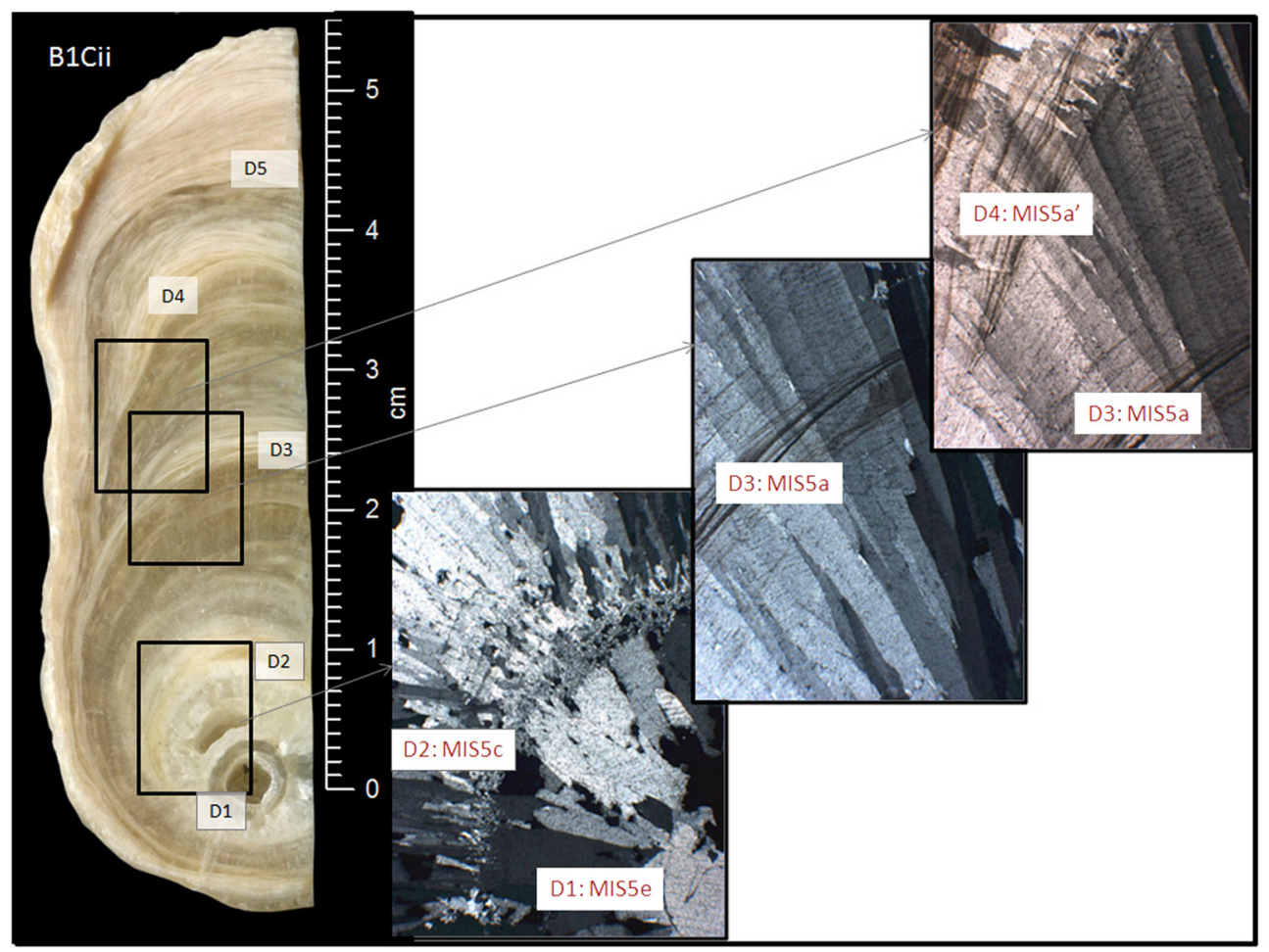

Fig. 4. Polished section of slice B1Cii from the QB stalactite and cross-polar light microscope images from vicinity of discontinuity D1 to D4.

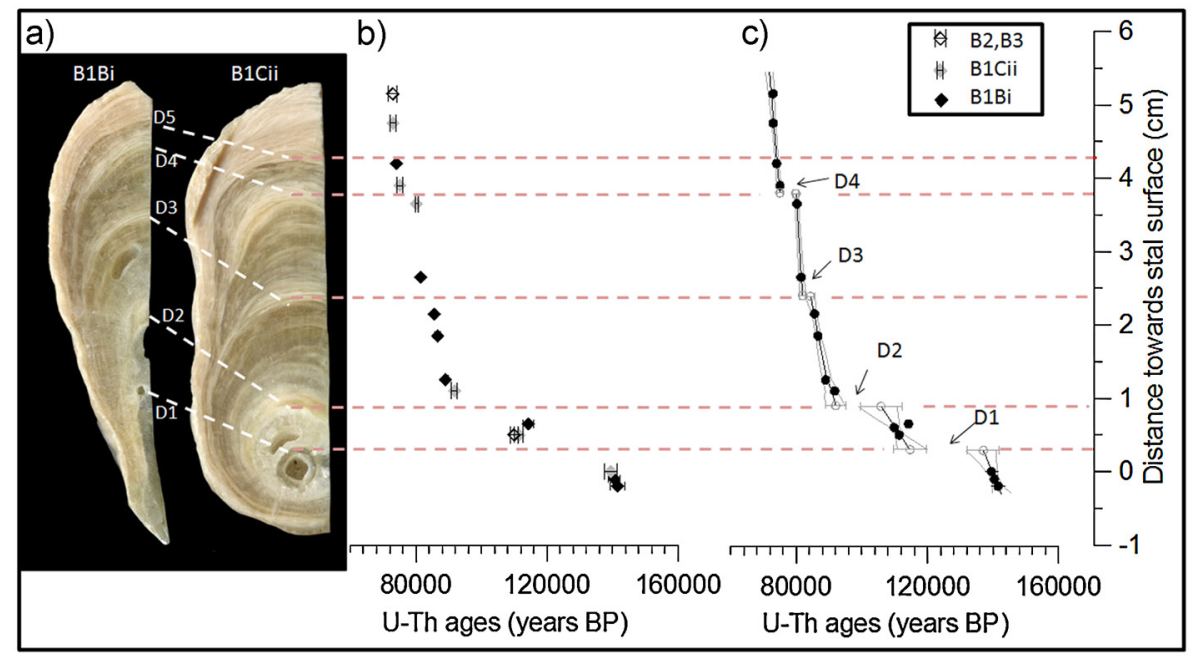

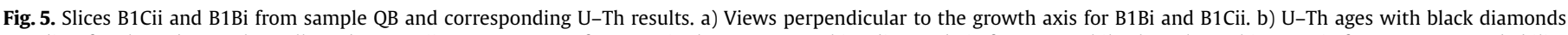

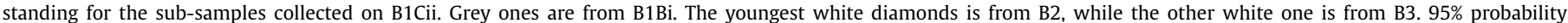

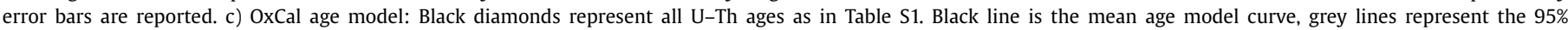

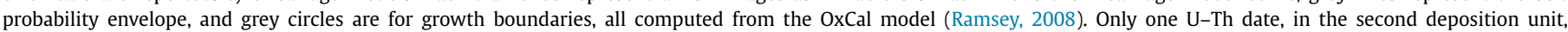

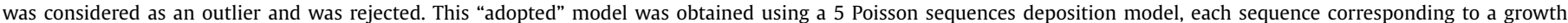
unit, limited by a growth hiatus. See supplementary material for more details. Four hiatuses appear as steps in the age model.

A local change in the cave could be caused by an obstruction of the fissures upstream from this stalactite and/or a change in the water pathway in the epikarst. To explain the data, such a hydrological phenomenon would have had to occur repeatedly and then reverse, simultaneously with sea level changes, which seems unlikely. A change in cave ventilation or a vegetation cover degradation could also imply speleothem growth cessation but this would be detected in the carbon isotopic composition of the speleothem calcite $\left(\delta^{13} C_{c}\right)$. As shown in Fig. $6(d)$, there is no specific $\delta^{13} C_{c}$ range or pattern showing up repeatedly at each discontinuity and D2 and D3 are more likely to be associated with enhanced vegetation rather than degradation, as the $\delta^{13} \mathrm{C}_{\mathrm{c}}$ values decrease.
Alternatively, regional atmospheric events, such as modifications of the climatic pattern in the North Atlantic, could have led to aridification, causing speleothem growth interruptions across Bermuda. Aridification would be expected to cause a rise in $\mathrm{Sr} / \mathrm{Ca}$ and $\mathrm{Mg} / \mathrm{Ca}$ in the stalactite due to increasing prior calcite precipitation in the overlying karst, but no evidence for such correlated increases either side of the hiatuses are observed in trace-metal data (Fig. S7) arguing against changes in rainfall. There is also evidence for growth of speleothem at greater height on Bermuda during one of the hiatuses (D1; Fig. 6, Hearty et al., 1999) indicating continued rainfall during that period. The hiatuses also do not correlate with particular changes in temperature or ocean 
Table 1

Characteristics of the discontinuities in sample QB. Ages and uncertainties are based on the OxCal modelling of new U-Th age data of this study.

\begin{tabular}{|c|c|c|c|c|c|}
\hline Discontinuity ID & $\begin{array}{l}\text { Age ka BP } \\
\text { ( } 2 \sigma \text { uncertainties) }\end{array}$ & MIS & $\begin{array}{l}\text { Duration } \pm 2 \sigma \\
\text { (ka) }\end{array}$ & Petrographic change & $\begin{array}{l}\text { New generation with } \\
\text { competitive crystal growth }\end{array}$ \\
\hline Discontinuity in M777 & $159-83.5$ & $5 e-d-c-b$ & 79.5 & Biogenic incrustation & No observation \\
\hline \multicolumn{6}{|l|}{ Discontinuities in QB } \\
\hline D1 & $137.0 \pm 4.9$ to $114.7 \pm 4.5$ & $5 e$ & $22.4 \pm 7.0$ & DCC to WPC large and fragile crystals & yes, continuously \\
\hline D2 & $105.9 \pm 6.4$ to $92.0 \pm 3.1$ & $5 c$ & $13.8 \pm 7.1$ & WPC to generally denser calcite & No \\
\hline D3 & $84.3 \pm 1.5$ to $82.0 \pm 1.1$ & $5 a$ & $2.4 \pm 1.8$ & $\begin{array}{l}\text { Set of more porous layers, appearing } \\
\text { whitish in between two denser calcite } \\
\text { deposition episodes }\end{array}$ & No \\
\hline D4 & $79.9 \pm 0.9$ to $75.0 \pm 0.8$ & $5 a^{\prime}$ & $4.9 \pm 1.2$ & $\begin{array}{l}\text { Set of more porous layers, appearing } \\
\text { whitish in between two denser calcite } \\
\text { deposition episodes }\end{array}$ & At some places \\
\hline D5 & & & & $\begin{array}{l}\text { DCC to WPC with an increasing } \\
\text { occurrence of clayey layer }\end{array}$ & No \\
\hline
\end{tabular}
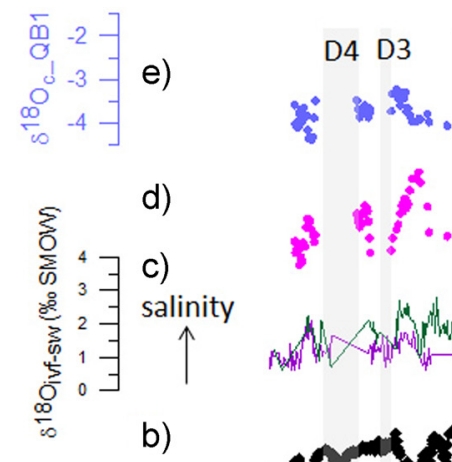

D2<smiles>CC(C)C1CCCCC1</smiles><smiles>C[13CH][13CH]</smiles><smiles>C[13CH2][13CH2][13CH3]</smiles>
$\therefore$

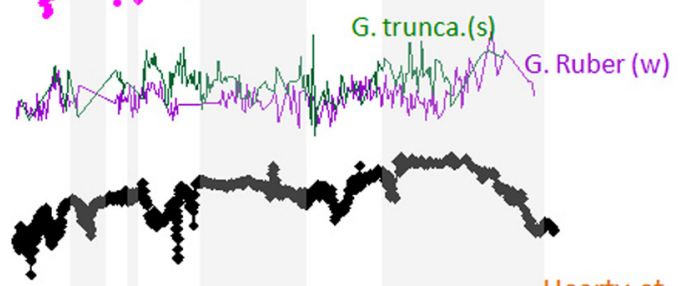

a)

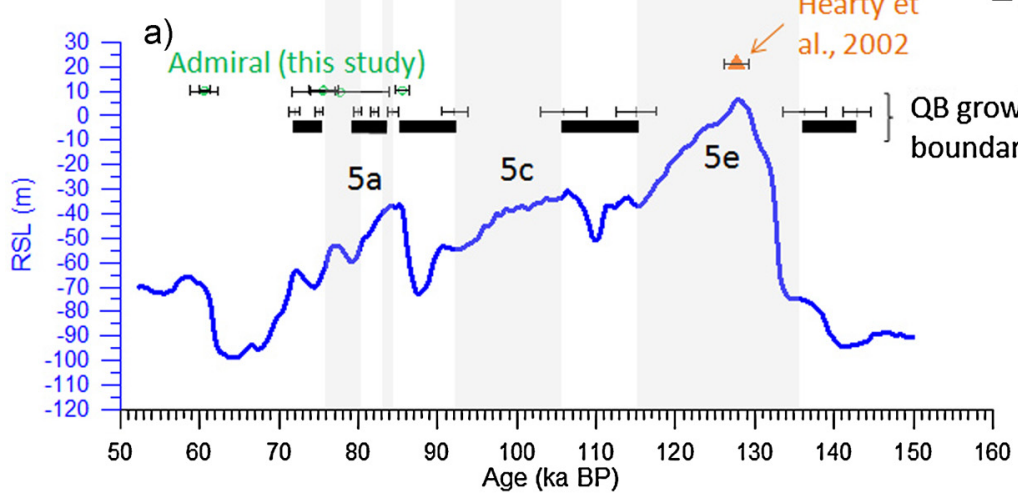

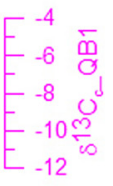

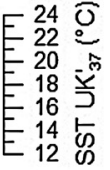

wth \& growth

Browth\&

160

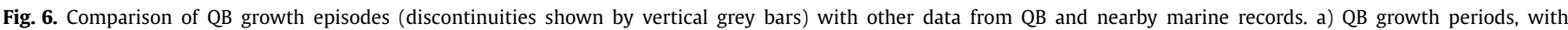

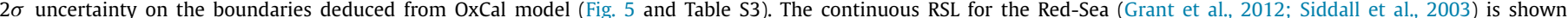

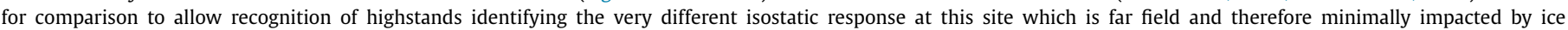

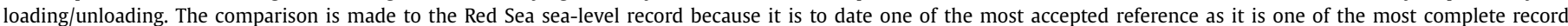

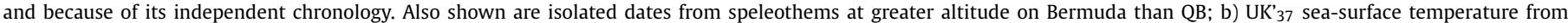

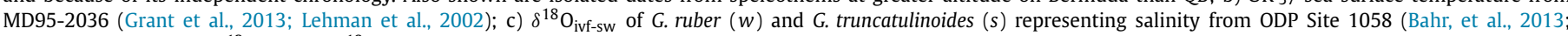
Fig. 1 for location); (d) $\delta^{13} \mathrm{C}$ and (e) $\delta^{18} \mathrm{O}$ of the QB speleothem carbonate along a radial transect across B1Cii (this study).

salinity (a crude proxy for rainfall) in the region. They typically occur during warmer periods, which would likely favour more humid conditions, but without any particular relationship to temperature changes in nearby sites (e.g. Fig. 6), and salinity in the region is rather constant during the period studied here. Such evidence makes it unlikely that the hiatuses are due to dry episodes on Bermuda. Such periods of aridity are, in any case, not expected at Bermuda, which is located in the middle of the Atlantic, where persistent Westerlies have likely provided constant moisture supply. Climatic conditions are likely to have remained favourable to speleothem deposition at Bermuda throughout MIS 5, and these four hiatuses are therefore unlikely to be the product of episodic aridity.
An attempt to distinguish hiatuses caused by sea-level submersion from those due to other causes by chemical fingerprinting was attempted in this study. We were hoping to find increases in marine ions or a shift toward marine values in the stable isotope composition in proximity to the sea-level related discontinuities, but none were visible at the resolution of sampling we conducted (see Supplemental Material for further details, particularly Fig. S7).

The correspondence of hiatuses with known highstand periods, coupled to the continued growth of speleothems at greater elevation in Bermuda and the lack of any other evidence for changes in rainfall or vegetation, argues strongly that the breaks in growth relate to submergence of the sample during sea-level highstands. 


\subsection{Implications for RSL reconstruction at Bermuda}

The hiatuses dated in this study are continuous to the stump of the stalactite, requiring a minimum RSL above the elevation of the ceiling from which it grew at $+1.5 \pm 0.5$ masl. RSL is therefore above +1.5 masl at four times during MIS 5 (Table 1), correlating with MIS 5e, MIS 5c, and two periods within MIS 5a, as shown in Fig. 6 . The $0.5 \mathrm{~m}$ uncertainty apply to the elevation of the stump of the stalactite: the precision of this RSL reconstruction is certainly a bit larger due to tides amongst others, but allows to circumvent the large depth range associated to coral data reconstructions in the order of tens of meters (Hibbert et al., 2016).

The duration of the hiatuses, computed using the OxCal age model, provides a possible duration for the timespan when RSL was above $+1.5 \mathrm{~m}$ for these four periods (Table S1) although these must be considered maximum durations because of the remaining possibility of periods where lack of growth is not due to flooding.

Sea-level above $+1.5 \mathrm{~m}$ during MIS $5 \mathrm{e}$ comes as no surprise, with abundant observations around the world placing eustatic sea level up to $\approx+9 \mathrm{~m}$ above modern during this period (e.g. Kopp et al., 2009; Dutton and Lambeck, 2012; Dutton et al., 2015), and more limited data indicating Bermudian RSL above modern (e.g. coral deposits at +4 to +6 m dated 126-113 ka (Muhs et al., 2002) and 134 to $118 \mathrm{ka}$ (Harmon et al., 1983), and marine aragonite on speleothem at +3 to $+4 \mathrm{~m}$ growing from $\sim 130-110 \mathrm{ka}$ (Harmon et al., 1978) (Fig. 2).

That Bermudian RSL was above $+1.5 \mathrm{~m}$ during MIS $5 \mathrm{c}$ and MIS 5 a was previously unclear, and the new constraints from this study contribute significantly to the controversy about high-stand amplitude for these periods (e.g. Fig. 2). The MIS $5 c$ hiatus encompasses the ages of MIS5c coral fragment ages obtained by Harmon et al. (1978, 1983), and the MIS 5a hiatuses encompass ages of coral fragments and geomorphological evidence for highstand (Harmon et al., 1978, 1983; Vacher and Hearty, 1989; Hearty et al., 1992; Ludwig et al., 1996; Muhs et al., 2002). These correlations support the view that, although none of the dated coral fragments are in life position, they are nevertheless found in sediments that formed close to modern sea level.

Hiatuses in speleothem growth in this study argue against previous indications for lower sea level during MIS5c and 5a in speleothem data by Harmon et al. (1981, 1983), suggesting that these early studies lacked the precision and resolution of U-Th dating to reveal period of growth hiatus in the submerged sample.

The new data from this study provide strong evidence for Bermudian RSL above modern at MIS5c and MIS5a. Observations at other locations around the world place RSL significantly below modern at MIS5c and MIS5a. Such observations are not at odds with those presented here, but indicate the important role of isostatic adjustment in controlling the pattern of RSL, and the location of Bermuda on the glacial forebulge. New confidence in Bermudian RSL at MIS5c and 5a will help to constrain the history of this forebulge in relation to earth properties and ice-loading.

\subsection{Multiple rises during MIS5}

Two growth interruptions on the $\mathrm{QB}$ stalactite are documented during the MIS5a: from $84.3 \pm 1.5$ to $82.0 \pm 1.1 \mathrm{ka}$ and from $79.9 \pm 0.9$ to $75.0 \pm 0.8 \mathrm{ka}$ (referred as MIS5a' in Fig. 4, Tables 1 and S3, Fig. 6). The earlier of these is short ( $2.4 \pm 1.8 \mathrm{ka}$, Table 1$)$ and less clear in the texture of the sample but, if taken at face value, the data suggests the presence of two peaks in RSL. Such a pattern of sea level is consistent, within uncertainty, with the MIS5a Bermudian coral ages obtained by Muhs et al. (2002), and with the timing of the two first MIS5a sea-level rises of the Red Sea record (Fig. 6).
Previous studies suggesting a double highstand at MIS5a have been from tectonically active regions (e.g. Dumas et al., 2006; Potter et al., 2004; Surić et al., 2009), allowing the possibility that tectonic movements might drive observed RSL changes. The tectonic stability of Bermuda makes it very unlikely that the double RSL peak observed in this study can be explained by tectonic movement. This oscillation therefore appears likely to be due to a change in ice volume and therefore a global feature.

\subsection{Illustration of constraints for glacial isostatic adjustment modelling}

Bermudian RSL is characterised by highstands above modern at each of MIS5e, $5 c$ and $5 a$. This contrasts with sites from further south, which experience significantly lower highstands at MIS5c and 5a (Fig. 7). There is a clear RSL gradient from the forebulge sites such as Bermuda to the more far-field sites during these later MIS 5 highstands. Potter and Lambeck (2003) explained this contrasting behaviour with glacio-isostatic adjustment (GIA), testing specific changes in ice sheet geometry and Earth model parameters.

To illustrate the constraints that the data can place on the GIA models, we explore predictions for the Bermudian highstands from a set of GIA models tuned to reproduce the Red Sea RSL curve (Williams, 2016). The independent chronology (Grant et al., 2012) and continuous nature of the Red Sea RSL curve make it a good candidate for developing ice volume histories, and it has been a target for several such GIA modelling studies. Details of the GIA modelling and ice sheet development used in this study can be found in the Supplementary Material. While the following results cannot be considered a new model based on or tuned to the Bermudian data, they serve to illustrate the ability of GIA to cause the characteristic RSL gradients seen to extend across the WNAC region during MIS 5c and MIS 5a.

GIA model results depend on the ice history and Earth model parameters used in the model run, both of which are uncertain. We explore how Bermudian highstand data could constrain the range of values that are realistic for these important model inputs. We developed two ice histories with differing ice-dispersal templates. ICE 1 has an ice-dispersal template based on ICE-5G (Peltier, 2004) whereas ICE 2 has a template based on a 3-D algorithmic ice model (de Boer et al., 2014) (see Supplementary Material). The different dispersal templates result in differing locations and thicknesses of ice, as well as changes in individual ice-sheet volumes. We then explored, with a series of model runs, the effect of a range of Earth model parameters (i.e. the upper- and lowermantle viscosity) on the model predictions (Fig. 8). The range of upper- and lower-mantle viscosity values in Fig. 8 is sampled by 165 different sets, and this range of values encompasses the values considered in Potter and Lambeck (2003).

Most values of model parameters do not produce RSL above modern for all three MIS5 highstands at Bermuda, illustrating the ability of the data to constrain these input parameters. Models with high values of lower mantle viscosity (typically $>3 \times$ $10^{22} \mathrm{Pas}$ ), and upper mantle viscosity values of about 2 to $5 \times$ $10^{20} \mathrm{Pas}$, result in predictions of all three highstands being close to modern (Fig. 8). This subset of viscosity values are rather similar to those found to yield the best results by Potter and Lambeck (2003). A slow solid-Earth response to rapid changes of sea level during MIS5, generated by high lower-mantle viscosity, allows RSL at Bermuda to be above modern, while global mean sea level is much lower by the end of MIS $5 \mathrm{a}$.

Ice distribution also plays an important role in the RSL response at Bermuda, with ICE 2 generally producing a more consistent set of maxima near present-day values for this set of Earth models (Fig. 8). A key difference between ice dispersal models is that the Laurentide ice sheet is smaller in ICE 2 than in ICE 1 during MIS 6, 

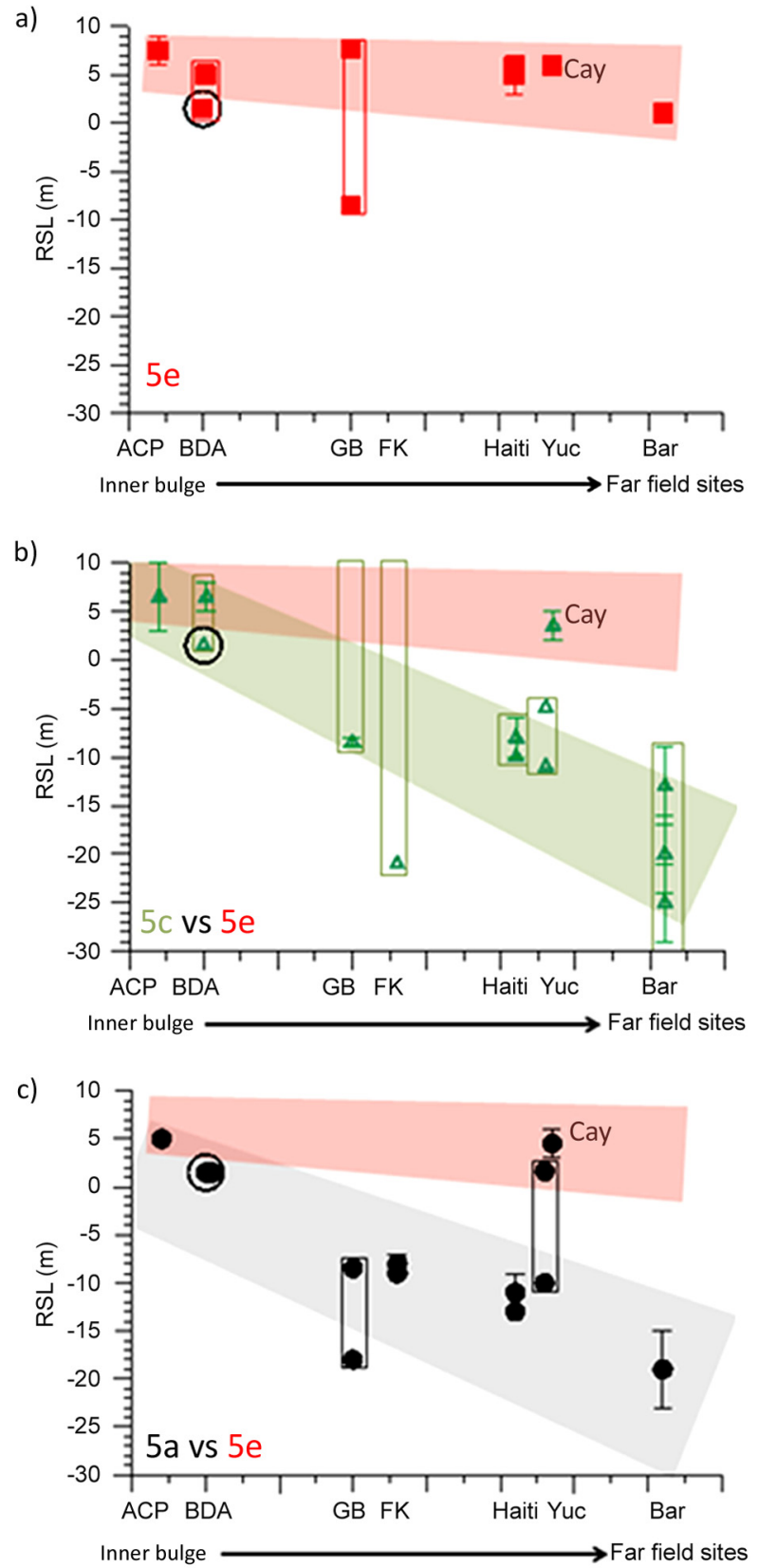

Fig. 7. Summary of RSL observations across the WNAC region including results in this study at MIS5e (red), 5c (green), and 5a (black), adapted from Potter and Lambeck, 2003. Symbols are used either when the RSL estimation is at a specific elevation or indicate the position of the indicator for a minimum or a maximum RSL (for instance the depth of a stalagmite that stopped growing.) Rectangles represent range of positions the RSL might have reached. In the absence of a RSL upper limit, rectangles are interrupted arbitrarily at $+10 \mathrm{~m}$. Shadings indicate the regional trend for each period. Data are provided for the US Atlantic coastal plain (ACP, Cronin et al., 1981; Wehmiller et al., 2004), Bermuda (BDA, Harmon et al., 1978, 1983; Vacher and Hearty, 1989; Muhs et al., 2002, this study empty circle), Grand Bahama (GB, Lundberg and Ford, 1994; Richards et al., 1994), the Florida Keys (FK, Ludwig et al., 1996; Toscano and Lundberg, 1999), Haiti (Dodge et al., 1983; Dumas et al., 2006), Yucatan, Mexico (Yuc, Moseley et al., 2013), Grand Cayman Island (Cay, Coyne et al., 2007) and Barbados (Bar, e.g. Radtke and Schellmann, 2005 as a review). Data from tectonically active places include uplift correction as provided by the authors. While consistent during MIS5e, a RSL gradient from inner bulge to far-field sites appear for the MIS5a and MIS5c highstands. (For interpretation of the references to colour in this figure legend, the reader is referred to the web version of this article.)

supporting the conclusions of Potter and Lambeck (2003), who found that a small, northerly North American ice sheet was suggested by available sea-level data.
The GIA modelling described here demonstrates the possibility to fit the gradient of sea-level change across the WNAC region during MIS 5 (e.g. Fig. 9) with RSL close to modern three times at Bermuda, but significantly lower in MIS5c and 5a further south (e.g. Yucatan and Barbados). The fit between models and data is not perfect, indicating the continued need for refinement in icesheet loads and earth properties in GIA models. We also note that Potter and Lambeck (2003) suggested that different values of upper mantle viscosity may be needed to successfully model observations in Bermuda versus the rest of the WNAC region, i.e. there must be lateral variations in upper mantle viscosity to explain the results. That RSL is above modern during each of MIS5e, $5 \mathrm{c}$ and $5 \mathrm{a}$ at Bermuda provides a powerful observational constrain for such future modelling, and will help to further understand ice-loading and forebulge evolution through time.

\section{Conclusion}

This speleothem study reveals relative sea-level variation history during MIS5 at Bermuda, a site located on the forebulge created by ice-loading during glacial periods. Based on speleothem $\mathrm{U}-\mathrm{Th}$ ages, relative sea level was higher than $1.5 \pm 0.5$ masl during the Last Interglacial highstand of MIS 5e and also during MIS5c and MIS5a, providing precise ages for these previously controversial later highstands. The results also suggest a double RSL rise at MIS5a, supporting previous evidence of a rapid sea level variation for this period and, given the tectonic stability of Bermuda, suggesting this is a global feature associated with changes in icesheet volume. Testing GIA models against these new constraints reinforces Potter and Lambeck's (2003) conclusions suggesting the presence of a smaller, northerly-based Laurentide ice sheet during the later MIS 5 and a restricted range of Earth viscosity values, with higher values of lower-mantle viscosity than are used in some GIA models of the Last Interglacial. That Bermudian sea level was above modern during MIS5c and 5a provides powerful constraints for future GIA models to help refine ice-sheet histories and Earth properties. It also demonstrates, more generally, the potential for highstands at this setting to be significantly higher than in other regions, helping to explain high sea level data for Bermuda from earlier highstands.

\section{Acknowledgements}

We are grateful to D. Summers who, as representative of the Wilkinson Estate, granted permission for access to the Wilkinson's Quarry Cave. G. Nolan and A. Mello are to be thanked for the invaluable assistance they provided to $\mathrm{M}$. Rowe in the collection of speleothems from Wilkinson's Quarry Cave. We thank C. Bronk Ramsey for his help in improving the age model, P. Holdship, C.C. Day, A. Hsieh for helping with trace metals, stable isotopes, U-Th measurements. D. Samson is thanked for his help in improving the figures and $\mathrm{O}$. Green for the thin section preparation. XRD analyses were done at GSI in collaboration with A. Ayalon and M. Bar-Matthews. We are also grateful to D. Ford and H. Schwarcz for providing the Crystal cave samples and to R. Smith and D. Petit at the Government of Bermuda for delivering both sampling and export permit and R. Chandler for his help in obtaining it. The National Museum of Scotland kindly provided access to samples from the Admiral's Cave. This work was supported by the NERC NE/1008861/1 and NE/I008365/1 (both iGlass). This is Contribution \#248, Bermuda Biodiversity Project (BBP), Bermuda Aquarium, Natural History Museum and Zoo, Department of Conservation Services. 

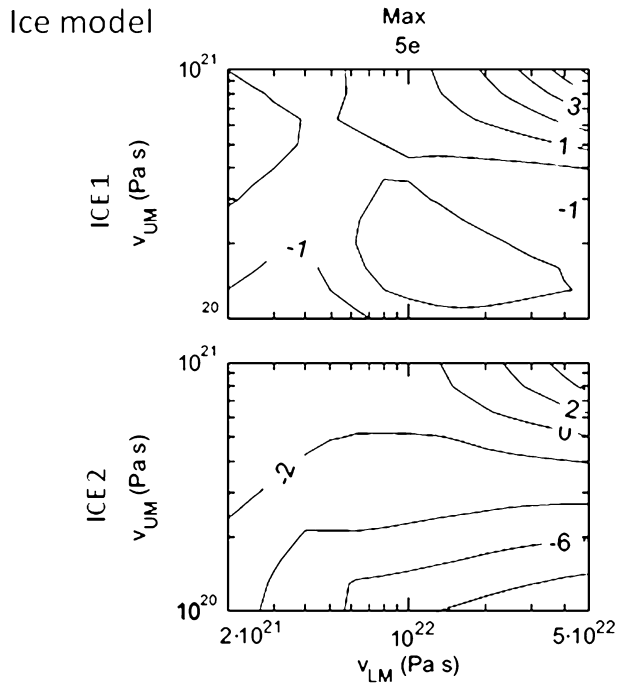
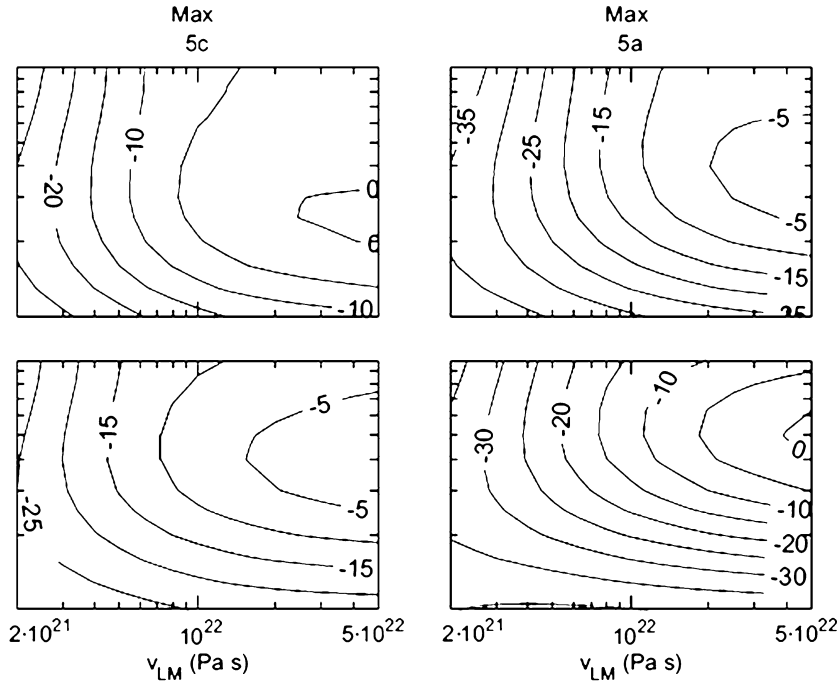

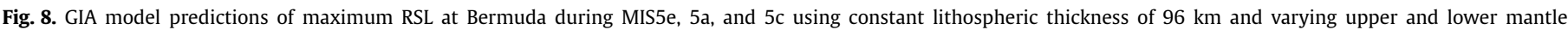

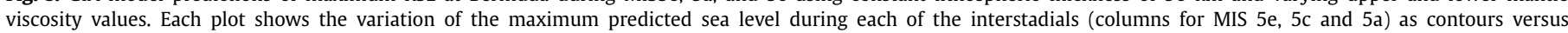

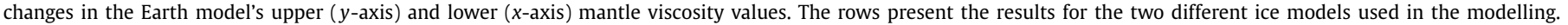

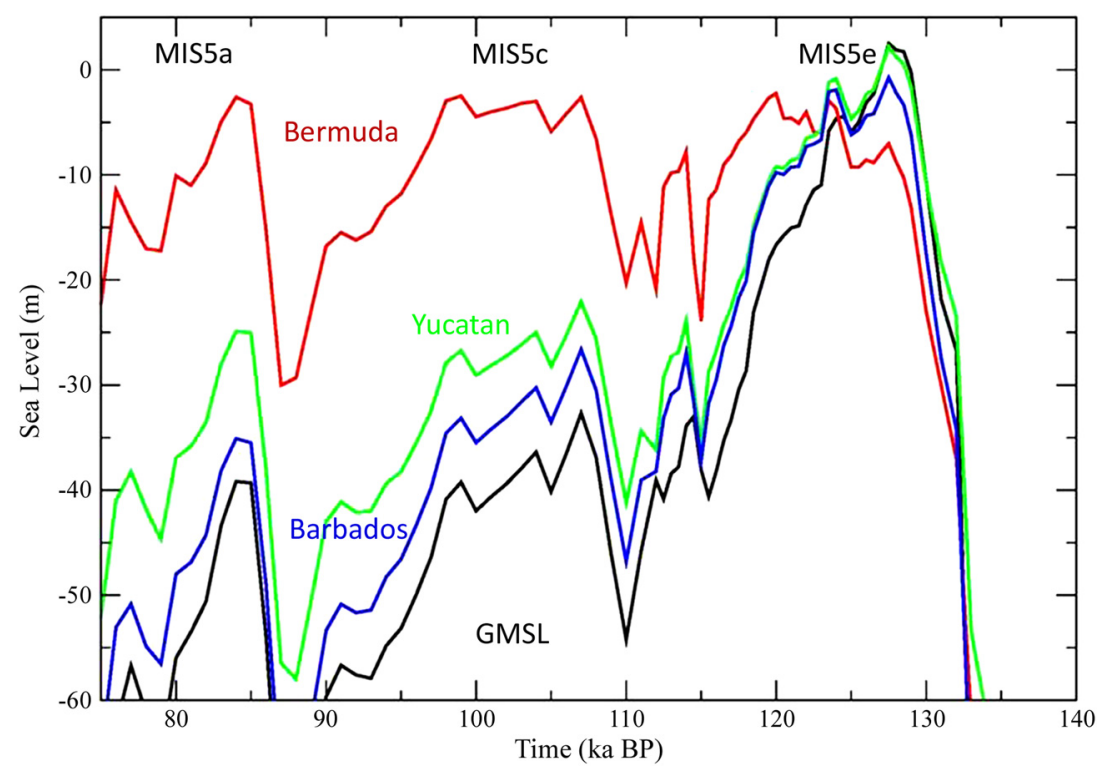

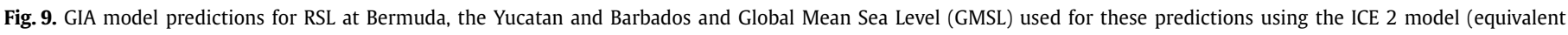

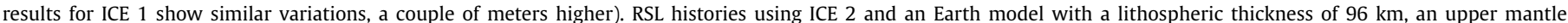

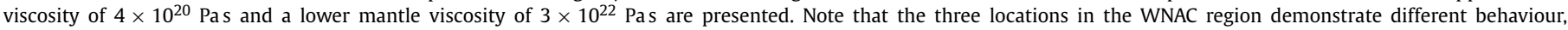
especially for $5 \mathrm{a}$ and $5 \mathrm{c}$.

\section{Appendix A. Supplementary material}

Supplementary material related to this article can be found online at http://dx.doi.org/10.1016/j.epsl.2016.10.005.

\section{References}

Bahr, A., Nürnberg, D., Karas, C., Grützner, J., 2013. Millennial-scale versus long-term dynamics in the surface and subsurface of the western North Atlantic Subtropical Gyre during Marine Isotope Stage 5. Glob. Planet. Change 111, 77-87.

Boop, L.M., Onac, B.P., Wynn, J.G., Fornós, J.F., Rodríguez-Homar, M., Merino, A., 2014. Groundwater geochemistry observations in littoral caves of Mallorca (western Mediterranean): implications for deposition of phreatic overgrowths on speleothems. Int. J. Speleol. 43, 193-203.

Coyne, M.K., Jones, B., Ford, D., 2007. Highstands during Marine Isotope Stage 5: evidence from the Ironshore Formation of Grand Cayman, British West Indies. Quat. Sci. Rev. 26, 536-559.

Cronin, T.M., Szabo, B.J., Ager, T.A., Hazel, J.E., Owens, J.P., 1981. Quaternary climates and sea levels of the U.S. Atlantic Coastal Plain. Science 211, 233-240. de Boer, B., Stocchi, P., van deWal, R.S.W., 2014. A fully coupled 3-D ice-sheet-sealevel model: algorithm and applications. Geosci. Model Dev. 7, 2141-2156.

Dodge, R.E., Fairbanks, R.G., Benninger, L.K., Maurrasse, F., 1983. Pleistocene sea levels from raised coral reefs of Haiti. Science 219, 1423-1425.

Dumas, B., Hoang, C.T., Raffy, J., 2006. Record of MIS 5 sea-level highstands based on U/Th dated coral terraces of Haiti. Quat. Int. 145, 106-118.

Dutton, A., Lambeck, K., 2012. Ice volume and sea level during the last interglacial. Science 337, 216-219.

Dutton, A., Webster, J.M., Zwartz, D., Lambeck, K., Wohlfarth, B., 2015. Tropical tales of polar ice: evidence of last interglacial polar ice sheet retreat recorded by fossil reefs of the granitic Seychelles islands. Quat. Sci. Rev. 107, 182-196.

Grant, J., Hopcraft, C., Borner, M., Haydon, D.T., 2013. Revived species: where will they live? Nature 493, 608.

Grant, K.M., Rohling, E.J., Bar-Matthews, M., Ayalon, A., Medina-Elizalde, M., Ramsey, C.B., Satow, C., Roberts, A.P., 2012. Rapid coupling between ice volume and polar temperature over the past 150,000 years. Nature 491, 744-747.

Harmon, R.S., Land, L.S., Mitterer, R.M., Garrett, P., Schwarcz, H.P., Larson, G.J., 1981. Bermuda sea-level during the last interglacial. Nature 289, 481-483.

Harmon, R.S., Mitterer, R.M., Kriausakul, N., Land, L.S., Schwarcz, H.P., Garrett, P., Larson, G.J., Vacher, H.L., Rowe, M., 1983. U-series and amino-acid racemization 
geochronology of Bermuda - implications for eustatic sea-level fluctuation over the past 250,000 years. Palaeogeogr. Palaeoclimatol. Palaeoecol. 44, 41-70.

Harmon, R.S., Schwarcz, H.P., Ford, D.C., 1978. Late Pleistocene sea level history of Bermuda. Quat. Res. 9, 205-218.

Hearty, P.J., 2002. Revision of the late Pleistocene stratigraphy of Bermuda. Sediment. Geol. 153, 1-21.

Hearty, P.J., Kindler, P., 1995. Sea-level highstand chronology from stable carbonate platforms (Bermuda and the Bahamas). J. Coast. Res. 11, 675-689.

Hearty, P.J., Kindler, P., Cheng, H., Edwards, R.L., 1999. A +20 m middle Pleistocene sea-level highstand (Bermuda and the Bahamas) due to partial collapse of Antarctic ice. Geology 27, 375-378.

Hearty, P.J., Vacher, H.L., Mitterer, R.M., 1992. Aminostratigraphy and ages of Pleistocene limestones of Bermuda. Geol. Soc. Am. Bull. 104, 471-480.

Heusser, L., Oppo, D., 2003. Millenial- and orbital-scale climate variability in southeastern United States and in the subtropical Atlantic during marine isotope stage 5: evidence from pollen and isotopes in ODP Site 1059. Earth Planet. Sci. Lett. 214, 483-490.

Hibbert, F.D., Rohling, E.J., Dutton, A., Williams, F.H., Chutcharavan, P.M., Zhao, C. Tamisiea, M.E., 2016. Coral indicators of past sea-level change: a global repository of U-series dated benchmarks. Quat. Sci. Rev. 145, 1-56.

Kopp, R.E., Simons, F.J., Mitrovica, J.X., Maloof, A.C., Oppenheimer, M., 2009. Probabilistic assessment of sea level during the last interglacial stage. Nature 462, 863-867.

Lambeck, K., Chappell, J., 2001. Sea level change through the last glacial cycle. Sci. Technol. Adv. Mater. 292.

Land, L.S., Mackenzi, Ft., Gould, S.J., 1967. Pleistocene history of Bermuda. Geol. Soc. Am. Bull. 78, 993.

Lehman, S.J., Sachs, J.P., Crotwell, M.A., Keigwin, L.D., Boyle, E.D., 2002. Relation of subtropical Atlantic temperature, high-latitude ice rafting, deep water formation, and European climate 130,000-60,000 year ago. Quat. Sci. Rev. 21, 1917-1924.

Ludwig, K.R., Muhs, D.R., Simmons, K.R., Halley, R.B., Shinn, E.A., 1996. Sea-level records at 80 ka from tectonically stable platforms, Florida and Bermuda. Geology 24, 211-214.

Lundberg, J., Ford, D.C., 1994. Late Pleistocene sea-level change in the Bahamas from mass-spectrometric U-series dating of submerged speleothem. Quat. Sci. Rev. 13, $1-14$

Marin, L.E., Perry, E.C., 1994. The hydrogeology and contaminant potential of northwestern Yucatan, Mexico. Geofís. Int. 33, 619-623.

Mason, A.J., Henderson, G.M., 2010. Correction of multi-collector-ICP-MS instrumental biases in high-precision uranium-thorium chronology. Int. J. Mass Spectrom. 295, 26-35.

Meischner, D., Vollbrecht, R., Wehmeyer, D., 1995. Pleistocene sea-level yo-yo recorded in stacked beaches, Bermuda South Shore. Spec. Pap., Geol. Soc. Am. 300, 295-310.

Moseley, G.E., Smart, P.L., Richards, D.A., Hoffmann, D., 2013. Speleothem constraints on marine isotope stage (MIS) 5 relative sea levels, Yucatan peninsula, Mexico. J. Quat. Sci. 2613.

Muhs, D.R., Simmons, K.R., Steinke, B., 2002. Timing and warmth of the Last Interglacial period: new U-series evidence from Hawaii and Bermuda and a new fossil compilation for North America. Quat. Sci. Rev. 21, 1355-1383.

Peltier, W.R., 2004. Global glacial isostasy and the surface of the Ice-age Earth: the ICE-5G (VM2) Model and GRACE. Annu. Rev. Earth Planet. Sci. 32.
Potter, E.K., Esat, T.M., Schellmann, G., Radtke, U., Lambeck, K., McCulloch, M.T., 2004 Suborbital-period sea-level oscillations during marine isotope substages 5a and 5c. Earth Planet. Sci. Lett. 225, 191-204.

Potter, E.K., Lambeck, K., 2003. Reconciliation of sea-level observations in the Western North Atlantic during the last glacial cycle. Earth Planet. Sci. Lett. 217 171-181.

Radtke, U., Schellmann, G., 2005. Timing and magnitude of sea level change during MIS 5 derived from Barbados coral reef terraces: a critical literature review and new data. J. Coast. Res., 52-62.

Ramsey, C.B., 2008. Deposition models for chronological records. Quat. Sci. Rev. 27 42-60.

Raymo, M.E., Mitrovica, J.X., 2012. Collapse of polar ice sheets during the stage 11 interglacial. Nature 483 .

Richards, D., Smart, P.L., Edwards, R.L., 1994. Maximum sea levels for the last glacial period from U-series ages of submerged speleothems. Nature 367.

Rohling, E.J., Grant, K., Bolshaw, M., Roberts, A.P., Siddall, M., Hemleben, C., Kucera, K., 2009. Antarctic temperature and global sea level closely coupled over the past five glacial cycles. Nat. Geosci. 2.

Rowe, M.P., Wainer, K.A.I., Bristow, C.S., Thomas, A.L., 2014. Anomalous MIS 7 sea level recorded on Bermuda. Quat. Sci. Rev. 90, 47-59.

Siddall, M., Rohling, E.J., Almogi-Labin, A., Hemleben, C., Meischner, D., Schmelzer, I., Smeed, D.A., 2003. Sea-level fluctuations during the last glacial cycle. Nature $423,853-858$.

Surić, M., Richards, D.A., Hoffmann, D.L., Tibljaš, D., Juračić, M., 2009. Sea-leve change during MIS 5 a based on submerged speleothems from the eastern Adriatic Sea (Croatia). Mar. Geol. 262, 62-67.

Tamisiea, M.E., Mitrovica, J.X., 2011. The moving boundaries of sea level change understanding the origins of geographic variability. Oceanography 24, 24-39.

Toscano, M.A., Lundberg, J., 1999. Submerged Late Pleistocene reefs on the tectonically-stable S.E. Florida margin: high-precision geochronology, stratigraphy, resolution of Substage 5a sea-level elevation, and orbital forcing. Quat. Sci. Rev. 18, 753-767.

Vacher, H.L., Hearty, P., 1989. History of stage-5 sea-level in Bermuda - review with new evidence of a brief rise to present sea-level during substage-5a. Quat. Sci. Rev. 8, 159-168.

Van Hengstum, P., Richards, D.A., Onac, B.P., Dorale, J.A., 2015. Coastal caves and sinkholes. In: Shennan, I., Long, A., Horton, B. (Eds.), Handbook for Sea-Level Research. John Wiley \& Sons, Oxford, pp. 83-103.

van Hengstum, P.J., Scott, D.B., Javaux, E.J., 2009. Foraminifera in elevated Bermudian caves provide further evidence for +21 m eustatic sea level during Marine Isotope Stage 11. Quat. Sci. Rev. 28, 1850-1860.

Vollbrecht, R., 1990. Marine and meteoric diagenesis of submarine Pleistocene carbonates from the Bermuda carbonate platform. Carbonates and Evaporites 5 13-95.

Wehmiller, J.F., Simmons, K.R., Cheng, H., Edwards, R.L., Martin-McNaughton, J., York, L.L., Krantz, D.E., Shen, C.C., 2004. Uranium-series coral ages from the US Atlantic Coastal Plain - the "80 ka problem" revisited. http://dx.doi.org/10.1016 j.quaint.2004.01.002.

Williams, F.H., 2016. A geophysical approach to reconstructing past global mean sea levels using highly resolved sea-level records. PhD Thesis. University of Southampton. 